2015

\title{
An Examination of Some Central Debates on Sex Trafficking in Research and Public Policy in the United States
}

Carrie N. Baker

Smith College, cbaker@smith.edu

Follow this and additional works at: https://scholarworks.smith.edu/swg_facpubs

Part of the Women's Studies Commons

\section{Recommended Citation}

Baker, Carrie N., "An Examination of Some Central Debates on Sex Trafficking in Research and Public Policy in the United States" (2015). Study of Women and Gender: Faculty Publications, Smith College, Northampton, MA.

https://scholarworks.smith.edu/swg_facpubs/7 


\section{An Examination of the Central Debates on \\ Human Trafficking Research and Public Policy in the United States \\ By Carrie N. Baker}

\section{Introduction}

Awareness of human trafficking has increased significantly since the passage of the Trafficking Victims Protection Act in 2000. We now regularly hear about trafficking from journalists like Nicholas Kristof of the New York Times, Hollywood movies like Taken with Liam Neeson, Hollywood celebrities like Ashton Kutcher and Demi Moore with their Real Men Don’t Buy Girls Campaign, and survivor activists touring the country speaking out against sex trafficking, like Rachel Lloyd, author of Girls Like Us. Even a government educational campaign titled "Look Beneath the Surface" is attempting to raise awareness about trafficking. A plethora of anti-trafficking non-governmental organizations have formed, like Polaris Project and International Justice Mission in Washington D.C., Shared Hope International in the state of Washington, and the Coalition Against Trafficking in Women, Equality Now, and Girls Educational and Mentoring Services in New York City. The current movement against sex trafficking is a complex movement with many voices coming from a diverse range of social, political and institutional locations, including academics, journalists, politicians, activists, and survivors. These activists are diverse, including feminists, evangelicals, humanitarians, liberals, and conservatives. The movement at first focused on sex trafficking framed as a problem that occurred outside the United States, particularly countries in Southeast Asia and the Newly Independent States in Eastern Europe and Asia. But gradually the problem came to be recognized as existing within United States borders, and involving not only non-citizen victims, 
but United States citizens as well (Baker, 2012). While at first the focus was primarily on sex trafficking, with labor trafficking receiving much less attention, today both sex and labor trafficking are receiving attention.

Public awareness and governmental action on human trafficking has increased tremendously since Congress passed the Trafficking Victims Protection Act in 2000. But this issue is not without controversy. In fact, there are intense debates about human trafficking. For example, in 2009, a groundswell of activists and attorneys general organized to pressure Craigslist to remove its "adult services" section of its website on the grounds that the website was used to traffic women and youth for sexual exploitation. Anti-trafficking activists were heavily involved in this campaign. A series of actions, including strongly worded editorials, a change.org petition titled "Petition to End Craigslist Sex Slave Trafficking" and a threatening letter from seventeen state attorneys general eventually led CEO Jim Buckmaster to close down the adult services section of Craislist.com in September of 2010 (which at the time had been bringing in $\$ 36$ million a year). The company at first blackened out the link with the word “censored." This closure led to heated arguments about free speech, moral policing of sexuality, and endangering sex workers by driving them underground and reducing their ability to work independently. It also led to claims that activists use falsely inflated numbers of sexually exploited youth, a position advanced in a series of articles in the Village Voice, owner of Backpage.com, now one of the most popular venues for adult service ads and the current target of anti-trafficking activists (Cizmar, Conklin \& Hinman, 2011). Other recent high-profile controversies have involved sex trafficking at the Superbowl and the government's requirement that organizations receiving federal dollars make an "anti-prostitution pledge" in order to receive federal support. 
These controversies are just a few of many heated debates about human trafficking that roil in newspapers, magazines and on the internet, but also, not surprisingly, in the scholarly literature and among feminists. The United States takes a law and order approach to trafficking, which prioritizes criminal prosecution of traffickers. This approach is supported by many in the United States anti-trafficking movement, including some feminists, but some activists, academics and service providers, both in the United States and abroad, have articulated powerful critiques of this approach, which the United States has exported around the world. The first part of this paper provides a general overview of some of the debates about trafficking in the United States focusing on five areas: definitions of human trafficking, the scope of the problem (how many people are trafficked and who are they), causes of and solutions to human trafficking, the effectiveness and impact of anti-trafficking laws, and anti-trafficking discourses - the ways the issues get framed and talked about. Understanding these points of contention and the political context in which these debates occur is critical to understanding and assessing human trafficking research and public policy in the United States. The second half of the paper will then provide a more in-depth examination of how these debates play out among feminist activists and academics, who have been deeply divided historically and still today on issues related to sexuality. Current feminist debates about trafficking echo the 1980s "sex wars" debate about prostitution and pornography, but are playing out in a global context of vastly different economic and political conditions. While abolitionist feminists have worked alongside conservative evangelicals to craft state-centered solutions to human trafficking, other feminists have opposed criminal justice approaches to trafficking that do not address structural economic and social factors that make people vulnerable to trafficking. 
Understanding feminist debates on human trafficking is important because these debates reveal underlying assumptions about sex, gender, sexuality, race and nation in human trafficking research and public policies, thereby revealing why this issue has risen to prominence at this particular historical moment and what's really at stake in these debates. Because opposition to human trafficking has brought together politically divergent interests, including feminists and evangelicals, Republicans and Democrats, the issue might appear to be nonpartisan and noncontroversial. This apparent consensus, however, is a myth. In fact, human trafficking is a highly divisive issue, characterized by intense debates. An understanding of these debates is critical to understanding research and public policy on human trafficking. Based on insights gleaned from understanding these debates, this essay will conclude with recommendations on guiding principles for future research and public policy.

\section{Definitions of Trafficking}

The first area of controversy is definitions of "human trafficking" and "sex trafficking." Sex trafficking is often conflated with human trafficking, perhaps in part because a disproportionate amount of popular and scholarly attention has been concentrated on sex trafficking. But in fact, legal definitions of human trafficking include many forms of human trafficking, including not only sex trafficking, but also labor trafficking, as well as other forms of trafficking like organ trafficking, child soldiers, and adoption trafficking. In 2000, the Trafficking Victims Protection Act (TVPA) created new federal crimes related to human trafficking and allocated significant federal funds to assist victims of severe forms of trafficking. TVPA defined sex trafficking to be "the recruitment, harboring, transportation, provision, or obtaining of a person for the purpose of a commercial sex act” (§103.9). No coercion or force is 
required, nor is transportation across state or national borders. The Act defines all prostitution ${ }^{1}$ as sex trafficking. A 2002 National Security Presidential Directive explicitly stated that the United States “opposes all prostitution and related activities," which it describes as "inherently harmful and dehumanizing" and "contributing to the phenomenon of trafficking in persons," and that "these activities should not be regulated as a legitimate form of work for any human being" (Bush, 2002, 2-3). ${ }^{2}$ However, despite the broad federal definition and policy position, the operative portions of the TVPA only apply to "severe forms of trafficking in persons," which is defined to require force, fraud or coercion, unless the victim is under 18 , in which case no force or coercion is required. In addition to sex trafficking, the Act separately prohibits labor trafficking, defined as "the recruitment, harboring, transportation, provision, or obtaining of a

${ }^{1}$ The use of the terms "prostitution" and "prostitute" are contested terms that some consider derogatory. As an alternative, many people use the terms "sex work" and "sex worker" (Bindman 1997), which some feminist abolitionists argue hide the violence inherent in the commercial sex industry (Farley 2006). In this chapter, I will use the terms used by those I am discussing.

${ }^{2}$ States have also passed laws with similarly broad definitions of sex trafficking (Polaris Project, 2012). For example, in 2011, Massachusetts passed an anti-trafficking law that defined "trafficking in persons for sexual servitude" to include anyone who knowingly, "subjects, or attempts to subject, or recruits, entices, harbors, transports, provides or obtains by any means, or attempts to recruit, entice, harbor, transport, provide or obtain by any means, another person to engage in commercial sexual activity, a sexually-explicit performance or the production of unlawful pornography” (Mass. Gen. Laws ch. 265, § 49). 
person for labor or services, through the use of force, fraud, or coercion for the purpose of subjection to involuntary servitude, peonage, debt bondage, or slavery” (§103.8). International law also defines human trafficking broadly. ${ }^{3}$

Controversy about definitions of human trafficking is widespread. One area of criticism is the conflation of sex trafficking with human trafficking and the lack of attention to labor trafficking. The United States government and many anti-trafficking activists have claimed that most human trafficking is sex trafficking of women and girls, and attention it the media and public policy has focused on sex trafficking (Wyler \& Siskin, 2010). Others, however, claim that labor trafficking is just as (or more) prevalent and important to address, and that sex trafficking

${ }^{3}$ Adopted in 2000, the United Nations protocol on human trafficking, also known as the Palermo Protocol, defines trafficking in persons to include "the recruitment, transportation, transfer, harbouring or receipt of persons, by means of the threat or use of force or other forms of coercion, of abduction, of fraud, of deception, of the abuse of power or of a position of vulnerability or of the giving or receiving of payments or benefits to achieve the consent of a person having control over another person, for the purpose of exploitation. Exploitation shall include, at a minimum, the exploitation of the prostitution of others or other forms of sexual exploitation, forced labour or services, slavery or practices similar to slavery, servitude or the removal of organs." Similar to United States law, the protocol does not require any force, fraud or coercion if trafficking involves someone under the age of eighteen and it does not require transportation across borders in any case. The Palermo Protocol does not have separate definitions for sex trafficking and labor trafficking, and it does not define sex trafficking to include any commercial sexual act, as United States law does. 
gets so much attention because of societal anxieties around gender and sexuality as well as race and migration (Kempadoo, 2005). Another debated area has been the focus on human trafficking outside the United States and the disproportionate allocation of resources to combatting trafficking abroad. Rachel Lloyd of Girls Educational and Mentoring Services (GEMS) in New York City, for example, testified before Congress in 2010 about the government's failure to address domestic sex trafficking of minors:

As a nation, we've graded and rated other countries on how they address trafficking within their borders and yet have effectively ignored the sale of our own children within our own borders .... Katya from the Ukraine will be seen as a real victim and provided with services and support, but Keshia from the Bronx will be seen as a "willing participant," someone who's out there because she "likes it" and who is criminalized and thrown in detention or jail (In Our Own Backyard, 2010).

Lloyd suggests that United States hypocrisy in condemning other countries for human trafficking while ignoring domestic trafficking might be due to a racialized tendency to blame victims within the American context. The issue of domestic minor sex trafficking has been the focus of a widespread campaign by several anti-trafficking organizations in the last several years. A third debated issue is how the law draws a line between children and adults at age 18. Critics have argued that this is an arbitrary and Westernized legal distinction that assumes a universal, developmental understanding that distinguishes a child from an adult (Davidson, 2005). Others argue that being under the age of 18 does not make that person any less aware of his or her situation or any less capable of making informed decisions (Iman et al., 2009).

But the area of most intense controversy is the definition of sex trafficking — and the equation of sex trafficking and prostitution, or sex work as some call it. Many abolitionists, 
particularly religious evangelicals and feminists, who are two prominent groups in the antitrafficking movement, argue that all prostitution is violence against women, and that no woman would engage in prostitution unless she had been forced or coerced so therefore all prostitution is sex trafficking (see, for example, Farley, 2006). On the other hand, advocates for sex workers argue that some women choose to engage in commercial sex, or have no other options to support themselves and their families, so they should be allowed to (Weitzer, 2007). Furthermore, they argue that anti-trafficking campaigns have a detrimental effect on sex workers, both in the United States and abroad because of brothel raids and increased surveillance of migrant women (Kempadoo et al., 2005). At the heart of this debate is the issue of consent-whether women can truly consent to engage in commercial sex acts, or whether the coercive economic, social, and political contexts in which some women appear to consent to engage in commercial sex obliterates any sort of true consent. This assumption of coercion, however, applies only to sex work, not to other forms of work. The definitional segregation of labor trafficking from sex trafficking bolsters this assumption by separating work involving sex from other forms of labor, thereby assuming a mutual exclusivity between legitimate labor and sex work (Hua \& Ray, 2010). This debate, which the second part of this paper will describe in more depth, was particularly intense in the drafting of the Palermo Protocol (Chapkis, 2003). Despite these debates, the prevalent tendency of states adopting laws today is to define sex trafficking broadly, such as the Massachusetts law discussed above.

\section{Scope of Trafficking}

Another area of controversy is the issue of how many people are trafficked. Varying definitions of human trafficking have led to a wide array of statistics. Estimates range from 2.4 million according to the United Nations Office on Drugs and Crime to 27 million according to 
Kevin Bales, founder of the anti-trafficking non-governmental organization (NGO) Free the Slaves. The International Labor Organization (ILO) — the United Nations agency charged with addressing labor standards, employment, and social protection issues - estimates that there are at least 20.9 million people in forced labor, bonded labor, forced child labor, and sexual servitude at any given time (ILO, 2012). There are also widely varying opinions about how many people are trafficked across borders each year, and who these people are-whether they are trafficked for sex or labor, and whether they are men, women and/or children. According to United States Government-sponsored research from 2003 that is still commonly cited, approximately 600,000 to 800,000 people are trafficked annually across national borders, which does not include millions trafficked within their own countries. This research claims that approximately eighty percent of transnational victims are women and girls, up to fifty percent are minors, and that the majority of transnational victims are females trafficked into commercial sexual exploitation. The United States government has also stated that 14,500 to 17,500 people are trafficked into the United States each year (Wyler \& Siskin, 2010).

But these numbers have been challenged by activists, researchers, and even the government itself (Weitzer, 2007). A 2006 Government Accountability Office (GAO) report called into question the numbers commonly used with regard to human trafficking. The report criticized these numbers for methodological weaknesses, gaps in data, and numerical discrepancies. According to the report, "the number was developed by one person who did not document all his work, so the estimate may not be replicable, casting doubt on its reliability. Moreover, country data are not available, reliable, or comparable. There is also a considerable discrepancy between the numbers of observed and estimated victims of human trafficking" (GAO, 2006, pp. 2-3). 
For domestic minor sex trafficking, the media and activist organizations commonly claim that as many as 100,000 to 300,000 (sometimes even 600,000 ) youths, primarily girls, are at risk of entering the commercial sex trade in the United States (some say 100,000 to 300,000 are in the sex trade), and that girls on average enter prostitution (or first become prostituted) between the ages of twelve and fourteen. But these claims have been hotly contested in the academic literature as speculative and based on flawed studies. According to Michelle Stransky and David Finkelhor of the University of New Hampshire's Crimes Against Children Research Center, "[These numbers] are mostly educated guesses or extrapolations based on questionable assumptions...The reality is that we do not currently know how many juveniles are involved in prostitution. Scientifically credible estimates do not exist" (Stransky \& Finkelhor, 2008, p. 2). The claim that girls are disproportionately the victims of domestic minor sex trafficking has also been challenged in a study by the Center for Court Innovation and John Jay College, which found that boys and transgender youth were 58\% of the commercially exploited youth in New York City (Curtis, Terry, Dank, Dombrowski \& Khan, 2008, p. 34).

These widely differing claims about the scope of the problem may be due in part to the fact that human trafficking is illegal activity that is hard to research. Researching illegal activities is challenging because of the underground nature of these behaviors. But unlike other illegal activities, like drug trafficking, human trafficking may be particularly challenging because survivors, particularly of sex trafficking, often experience shame and are reluctant to speak to researchers. In addition, many survivors are under 18, which can raise difficult legal and ethical issues. In the wake of the criminal allegations against Penn State's football coach Jerry Sandusky and indications that Penn State employees did not adequately respond to allegations against Sandusky, some states have passed laws making employees of higher educational institutions 
mandatory reporters of child sex abuse. For example, in 2012, Oregon passed a law requiring college employees to notify authorities about suspected abuse (House Bill 4016, 2012). Other states have considered or passed similar laws, such as Illinois (325 ILCS 5), Washington State (Senate Bill 5991, 2012), and California (Assembly Bill 1434, 2012). Laws such as these may have a chilling effect on research into the trafficking of minors because researchers are not able to ensure the confidentiality of those they interview

Another reason why the numbers vary so greatly is that definitions of trafficking used in research differ. They are sometimes extremely broad, as we've seen with regard to sex trafficking, which is often equated with prostitution/sex work, without regard to whether commercial sex is coerced or not. The controversy about the scope of the problem grows not only from the methodological difficulties of measuring human trafficking, but also because claims about how many people are trafficked, as well as how they are trafficked and who the victims are, shape public policy priorities and the allocation of resources. If advocates can claim that large numbers of people are affected, particularly children, then they have a stronger case for placing trafficking at the top of the public agenda and for allocating significant public resources toward its eradication. The scope of the problem also affects perceptions of the urgency of the problem. Advocates claiming high numbers of victims are more likely to be able to pressure legislators to act because of the claim that there is ongoing harm to so many people.

\section{Trafficking Causes and Solutions}

Another area of dispute is what are the causes and solutions to human trafficking. The dominant framing of the issue is that sex trafficking is a criminal justice problem that should be solved by passing criminal laws against trafficking and prosecuting traffickers. The TVPA takes this approach. The 2000 Act created a new federal crime of human trafficking, allocated 
resources for the prosecution of trafficking cases, and provided some assistance to victims willing to testify in criminal cases against defendants accused of trafficking. The Act also funded programs to increase public awareness and inform potential victims of trafficking about the law and their rights. The Act had only a brief section on creating economic alternatives for vulnerable populations, including microcredit lending programs, job training, and programs to keep girls in school, but these programs were not well funded (22 U.S.C. § 7104(a)). Subsequent reauthorizations of the Act in 2003, 2005, 2008 and 2013 have expanded upon the criminal justice approaches to sex trafficking. Furthermore, the United States has pressured countries around the world to adopt criminal justice solutions to human trafficking. The TVPA requires the Secretary of State to issue an annual Trafficking in Persons (TIP) report that evaluates nations deemed to be a country of origin, transit or destination for victims of severe forms of trafficking in persons. The criteria for evaluation are whether countries prohibit and prosecute human trafficking and whether they assist victims. The TVPA empowers the President to sanction noncompliant nations by denying them nonhumanitarian, nontrade-related assistance. This dominant criminal justice framing was summed up in a statement made by the founder of the International Justice Mission Gary Haugen in a New York Times Magazine story: "Sex trafficking isn't a poverty issue but a law enforcement issue” (Landesman, 2004, pp. 36-37). This quotation reflects how Haugen focuses on criminal justice solutions to trafficking rather than broader social and economic conditions that create vulnerable populations.

But some activists and scholars have criticized this criminal justice approach as too narrow, arguing that root causes of trafficking must be addressed to end trafficking - the economic, political and social conditions that make people vulnerable to trafficking, such as poverty, global wealth inequality, lack of citizenship, war, racial discrimination, and traditional 
gender ideologies that devalue women and girls. These critics call for structural changes, like public policies that address lack of economic opportunities and relax restrictive immigration laws (Kempadoo, 2005). This approach, they argue, focuses on empowerment of the oppressed rather than rescue and protection of women and girls. Some argue that the TIP evaluation process is politicized, so that United States allies receive more lenient treatment than United States enemies (Soderlund, 2005, 76-77). Another argument is that the TVPA TIP evaluation process imposes a universal, one-size-fits-all, top-down solution on diverse countries around the world, which fails to recognize the actual conditions of trafficking. Scholar Rhacel Salazar Parrenas (2006) argues for a bottom-up approach that takes into account different groups' experiences of trafficking, recognizing multiple forms of trafficking and multiple solutions, as well as focusing on improving conditions of labor and migration and addressing severe structural constraints, like poverty, that create vulnerability to trafficking. Despite these objections, the criminal justice framing of trafficking has been dominant both in the United States and abroad. Most public policy on trafficking focuses on criminal justice causes and solutions to trafficking and does not address broader structural causes like poverty, gender inequalities, or racism.

\section{Effectiveness and Impact of Anti-Trafficking Laws}

A fourth area of debate relates to the impact of anti-trafficking laws, in particular border monitoring, raid and rescue methods, victim assistance, and NGO funding. The TVPA evaluates governments for the purposes of the TIP report on whether they "monitor immigration and emigration patterns" for evidence of trafficking and whether they pursue "vigorous investigation and prosecution" if they find any such evidence (22 U.S.C. §7106). Critics of this policy argue that this requirement has led to increased surveillance of borders and stricter enforcement of immigration restrictions (Sharma, 2005). They argue that these restrictions discourage migration, 
particularly of women and girls, but that many women need to migrate to gain access to education and employment (Temin, Montgomery, Engebretsen, \& Barker, 2013). The Global Alliance Against Trafficking in Women (GAATW) has argued that anti-trafficking initiatives have, in fact, violated the human rights of women deemed victims of trafficking, such as confining them to shelters or sending them back to their countries of origin against their will (GAATW 2007). Critics argue that migration restrictions and tighter border enforcement could actually increase women's vulnerability to trafficking by making migration riskier and more costly thus exposing them to greater exploitation. These critics note the close relationship historically and today between anti-trafficking and anti-migration agendas. Jo Doezema (2000) argues that the nineteenth and early twentieth century "white slave trade" scare was motivated by anxieties around changing gender roles, sexuality, and migration, suggesting that similar concerns motivate post-9/11 anti-trafficking policies (see also, Chapkis, 2003). Gender roles are changing, with women bringing home a larger share of household income and increasingly likely to parent alone. Changing sexual norms are reflected in the destigmatization of non-marital sex for women and in gains won by the gay and lesbian rights movement, including the elimination of criminal prohibitions against sodomy and increasing legalization of same-sex marriage. These factors, combined with globalization and the "war on terror," could be generating anxieties that motivate the anti-trafficking movement and its broad appeal.

A second concern about the impact of anti-trafficking laws is the United States government's support of law enforcement's "raid and rescue" methods, where brothels are raided and people believed to be trafficked are removed and placed in rehabilitation (Office to Monitor and Combat Trafficking in Persons, 2012). Critics argue that anti-trafficking laws and raids lead to the arrest and imprisonment non-trafficked sex workers. They argue that this criminalization 
endangers sex workers and may make them more vulnerable to trafficking (Ditmore \& Thukral, 2012). A third critique of anti-trafficking law is that the TVPA allows foreign national victims in the United States to obtain visas and services only if they are willing to assist "in every reasonable way in the investigation and prosecution of severe forms of trafficking in persons" (22 U.S.C. §7105). Critics have argued that many victims are not willing to testify against their traffickers so few have applied for visas and assistance. Finally, as of 2003, the United States has required non-governmental organizations (NGOs) that receive anti-HIV/AIDS or anti-trafficking funds to pledge that they oppose the legalization of prostitution (US Leadership Against HIV/AIDS, Tuberculosis and Malaria Act of 2003, 22 U.S.C. $§ 7631$ and Trafficking Victims Protection Reauthorization Act of 2003, 22 U.S.C. $§ 7110$ ), a policy initially enforced only against foreign-based NGOs but later extended to United States-based NGOs as well. In July of 2013, the United States Supreme Court in United States Agency for International Development v. Alliance for Open Society International, Inc. ruled that the requirement that domestic NGOs make an anti-prostitution pledge in order to receive government funds was unconstitutional (however, the pledge remains in place for NGOs abroad). Critics say that the anti-prostitution pledge has led to the defunding of sex worker organizations that have had some of the most effective anti-HIV/AIDS programs, thereby endangering sex workers (Center for Health and Gender Equity, 2008). Despite these criticisms, public policies relating to migration, the raid and rescue method, victim assistance, and international NGO funding remain in place.

\section{Anti-Trafficking Discourses}

The fifth area of controversy is how sex trafficking is portrayed in mainstream public discourses. Anti-trafficking discourses often follow a rescue narrative, where an innocent, helpless female is rescued from an evil trafficker by a heroic rescuer. Innocence is portrayed by 
focusing on extremely young victims or, in film, focusing on the preservation of a girl's virginity, as in the Hollywood movies Trade and Taken or the independent film Holly (Baker, 2013a). The rescuers, on the other hand, are usually heroic men, especially in film. The language of protection and rescue is pervasive. The title of the United States law, Trafficking Victims Protection Act, and the government's Rescue and Restore Campaign reflect this framing. Some criticize the framing of trafficking in terms of protection and rescue for being paternalistic and disempowering to women (Bernstein 2007; Parreñas 2006). Others argue that media and activist portrayals of human trafficking rely on traditional ideologies of gender, portraying the extreme sexual vulnerability and helplessness of women and girls, the absence of men as victims, and the hypermasculinity of male rescuers. Elizabeth Bernstein (2007) argues that evangelical Christians, in particular, frame their campaigns in terms of the "rhetoric of violated femininity, shattered innocence, and the victimization of "womenandchildren"' (p. 133). These portrayals, some argue, might reinforce the very ideologies that contribute to the prevalence of trafficking (Baker, 2013b). Furthermore, critics note that traditional ideologies of race and nation also pervade these discourses. Julietta Hua (2006) argues that media stories about trafficking are peppered with "generic brown bodies in unnamed third world locales" (p. 55) and that these stories often suggest the civilization of the West in juxtaposition with third world backwardness that allows trafficking to happen. The common rescue narrative portrays white men and women who "rescue brown women from brown men" (Spivak 1988; see also Mohanty 2006). Even the language of slavery is controversial. Julia O'Connell Davidson (2010) has argued that “discourse of 'trafficking as modern slavery' revitalizes liberal understandings of freedom and restriction that have historically allowed vigorous moral condemnation of slavery to coexist with the continued imposition of extensive, forcible restrictions on individuals deemed to be "free" (Davidson, 
2010). These objections, however, have done little to change the mainstream framing of trafficking.

These are just some of the areas that are debated about human trafficking today. Despite these debates, the predominant view is that human trafficking should be defined broadly, that the number of victims is high—particularly sex trafficking victims, that the cause is criminals and the solution criminal prosecution, that anti-trafficking laws are effective, and that the ways stories about human trafficking are told is true and/or necessary to motivate people to act.

\section{Feminist Debates on the Sex Trade and Trafficking}

These broader debates have played out in particular ways among feminists. Some feminists have been strong advocates of the anti-trafficking cause, while other feminists have been highly critical of the movement. These divisions echo the rancorous clefts of the 1980s' “sex wars" that so splintered feminists (Duggan \& Hunter, 2006). Like the anti-pornography movement of the 1980 s, the contemporary anti-trafficking movement has produced strange bedfellows and a counter-movement: some feminist abolitionists have aligned with religious conservatives working against sex trafficking and prostitution. On the other hand, some feminists who advocate for sex workers support decriminalization of prostitution and harm reduction approaches to sex work. Many are critical of feminist support for criminal justice solutions to trafficking and argue that feminist abolitionists see women only as victims in need of rescue, which reinforces traditional gender ideologies. Whereas in the 1980s feminists were divided on the harmfulness of pornography and free speech issues, today on the issue of sex trafficking, feminists are divided around all of the issues described above, including the definition and scope of trafficking, the primary causes and best solutions to trafficking, the impact of anti-trafficking 
laws, and the rhetoric and framing of the issue in public discourses. This section will describe the origins of feminist abolitionism, its critics, and their arguments.

The leading feminist abolitionist group in the United States, ${ }^{4}$ the Coalition Against Trafficking in Women (CATW), was founded in 1989 by anti-pornography activists Dorchen Leidholdt and Norma Ramos, both of whom were active in the prominent anti-pornography group Women Against Pornography in the 1970s and 1980s (Bronstein, 2011). Another early feminist abolitionist, Laura Lederer, worked in the anti-pornography movement and later founded The Protection Project, a leading legal research institute to combat human trafficking. Lederer played a key role in forging a bi-partisan coalition of anti-trafficking groups that included women's groups like Equality NOW and conservative religious groups such as the Salvation Army and the National Association of Evangelicals. This coalition played an important role in the passage of the Trafficking Victims Protection Act in 2000. After passage of the law, Lederer worked within the federal government to implement the TVPA, becoming the Senior Advisor on Trafficking in Persons in the Office for Democracy and Global Affairs of the United States Department of State. This coalition of feminists and religious conservatives is perhaps best demonstrated by a statement about George Bush by prominent feminist anti-trafficking activist and women's studies professor Donna Hughes: “mainstream feminists like to say he's antiwoman, but by supporting the abolitionist work against the global sex trade, he has done more for women and girls than any other president I can think of...Years from now, when the anti-

\footnotetext{
${ }^{4}$ I focus this discussion primarily on anti-trafficking activism in the United States, although there are many prominent feminist anit-trafficking groups outside of the United States, such as the Global Alliance Against Traffic in Women, which is based in Thailand.
} 
Bush hysteria has died away, I believe he will be recognized as a true advocate for women's freedom and human rights" (Lopez, 2006).

Feminist abolitionists come from a range of backgrounds, including survivors and social service providers, lawyers and scholars. Rachel Lloyd of GEMS in New York City and Vednita Carter of Breaking Free in Minneapolis are both survivors running organizations to help women and girls leave the commercial sex trade. Other feminist abolitionists have founded and/or run non-governmental organizations that do research, public education and legal advocacy against trafficking. Lawyer Norma Ramos leads CATW, with Carter serving on their board. Melissa Farley, a clinical psychologist and founder and director of Prostitution Research and Education in San Francisco, is a leading researcher on prostitution and trafficking. Equality NOW in New York City, which was led for many years by feminist abolitionist Taina Bien-Aimé, has waged several campaigns against sex tourism and lobbied for the TVPA and its reauthorizations, the Palermo Protocol, and anti-trafficking legislation in New York. The Minnesota Indian Women's Resource Center is an abolitionist feminist organization that has worked on the commercial sexual exploitation of American Indian women and girls (Pierce 2009). Prominent feminist scholars working against trafficking include Donna Hughes (University of Rhode Island), Catherine MacKinnon (University of Michigan School of Law), and Sheila Jeffries (University of Melbourne).

Those critical of the anti-trafficking movement also include activists and scholars, such as Portland-based activist emi koyama, Crystal DuBoise of the Sex Workers Project in New York City, Wendy Chapkis of University of Southern Maine, Elizabeth Bernstein of Barnard 
College, and Ronald Weitzer of George Washington University. ${ }^{5}$ Some prominent United Statesbased sex-worker organizations that are critical of the anti-trafficking movement are Desiree Alliance, Best Practices Policy Institute, and Sex Workers Outreach Project USA, and the youth collectives Young Women's Empowerment Project in Chicago and Different Avenues in Washington D.C. These critics challenge feminist abolitionists on all of the issues raised above: the definitions of human trafficking, the scope of trafficking, causes of and solutions to human trafficking, the effectiveness and impact of anti-trafficking laws, and anti-trafficking discourses.

On definitions, many feminist abolitionists like Lloyd, Carter, Farley and MacKinnon equate prostitution with sex trafficking, believing that all commercial sex is violence against women and that women never freely consent to engage in commercial sex. By arguing that all prostitution is trafficking, abolitionists often focus on the coercive economic and social circumstances. For example, Melissa Farley argues that prostitution is a "choice made by those who have no choice" and that in fact global forces "choose" women and girls for prostitution, forces like "sex discrimination, race discrimination, poverty, abandonment, debilitating sexual and verbal abuse, poor education or no education, and a job that does not pay a living wage" (Farley 2006). Abolitionists separate sex work from other forms of work to which women can consent (Hua \& Ray, 2010). On the other hand, emi koyama, Laura Agustin and Wendy Chapkis

\footnotetext{
${ }^{5}$ Other important voices are independent scholar Melissa Ditmore, Ann Jones (American University), and Nandita Sharma (University of Hawaii), as well as several scholars from outside of the United States, such as Kamala Kempadoo (York University), Julia O’Connell Davidson (University of Nottingham), scholar/activsit Jo Doezema of the Paulo Longo Research Initiative in Lima, Peru, and independent scholar Laura Agustin.
} 
make a clear distinction between consensual engagement in the sex trade and sex trafficking, sometimes even when minors are involved. These advocates argue that women and girls can consent to engage in sex work even in the face of coercive economic and social circumstances, sometimes characterizing that choice as an act of agency. They critique feminist abolitionists for their disproportionate focus on sex trafficking over trafficking into other kinds of work, like domestic service, where women often experience sexual abuse (koyama, 2011a; Agustin, 2007; Chapkis, 2003). By focusing on whether sex can be work and sex work can be consensual, contemporary feminist debates on sex trafficking echo the 1980 s feminist debates on prostitution and pornography.

On the scope of the problem, feminist abolitionist organizations like GEMS cite the commonly-used statistics that 100,000 to 300,000 children are at risk for entering the sex trade and that girls most frequently enter the sex trade between the ages of twelve and fourteen (http://issuu.com/gems/docs/gems_brochure_2012/1). Emi koyama (2011a, 4-9), on the other hand, has argued that these numbers are inflated and based on studies with methodological flaws, as has Ronald Weitzer (2007), who has criticized feminist research methods for lacking objectivity (Weitzer, 2011). Koyama has also criticized the anti-trafficking movement for ignoring transgender youth (koyama, 2011b, 19).

On causes and solutions, abolitionist feminists like Melissa Farley and Donna Hughes focus on male demand for sex as the primary cause of trafficking and support the criminalization of prostitution, versus pro-sex work feminists like Kelli Dorsey or Crystal DuBoise who focus on empowering women to be able to make the choice of whether to enter prostitution- to leave prostitution if they choose, but also to enter it legally if they need to or want to. While many feminist abolitionists support the "Swedish model," which criminalizes the buyers of sex but not 
the sellers, American University law professor Ann Jordan (2012) argues there is no reliable evidence that the Swedish model has reduced the sex trade or trafficking in Sweden and that it may in fact be increasing the risk of violence, stigma, negative outcomes, and police harassment of sex workers, while decreasing the likelihood that buyers will testify in cases of trafficking and abuse. In fact, many pro-sex work feminists call for decriminalization or legalization of the sex trade as a way of decreasing the abuse of sex workers. FUSE, an affiliate of the group Incite! Women of Color Against Violence, is critical of anti-trafficking laws because they argue that these laws have increased the criminalization of communities of color in the United States (FUSE 2011). Emi koyama argues that the anti-trafficking movement has supported "militaristic responses to prostitution and sex trafficking that focus on law enforcement approaches to target and convict the evil pimps, traffickers, and johns" (koyama 2011a, 29). Elizabeth Bernstein is critical of "carceral feminism," which she defines as "a vision of social justice as criminal justice, and of punitive systems of control as the best motivational deterrents for men's bad behavior" $(2010,58)$. These differences echo the longstanding debate within U.S. feminism between white, well-educated, professional women who align with liberal legal approaches to violence, which they advocate globally, and women of color feminists in the United States and abroad, who are critical of criminalization and the state as a solution to violence against women (Bumiller 2008).

Interestingly, feminists on both sides of this debate make some similar arguments but come to very different conclusions. For example, they both argue that structural factors like sexual, racial and class hierarchies make women and girls vulnerable to trafficking, but feminist abolitionists then argue for criminal prohibitions of prostitution and trafficking as the best way to decrease the harm of these structural inequities, whereas anti-abolitionist feminists argue that the 
criminal justice system exacerbates sexism, racism and classism and therefore feminists should not to align themselves with the state and law enforcement to combat trafficking. On the abolitionist side, Melissa Farley (2006) argues that those who support legalization of prostitution ignore the global forces that choose women for prostitution, which include sex discrimination, race discrimination, poverty, poor education or no education, and lack of living wage jobs. Farley notes how prostitution systemically discriminates against women, the young, the poor, and ethnically subordinated groups. She objects to the phrase "sex work" because she believe it hides the sexism, racism, and violent degradation of prostitution, which is normalized as glamorous and falsely portrayed as a wealth producing job. Feminist abolitionist and philosopher Kathy Mirian (2005) argues that those who support legalized prostitution assume liberal individualism — that individuals are autonomous and choice is the exercise of the individual's autonomous will—which, she argues, obscures relations of power, dominance and submission inherent in patriarchal capitalism.

To the contrary, other feminist scholars argue that the anti-trafficking agenda has reinforced oppressive economic and social systems. Kamala Kempadoo (York University) argues that the trafficking paradigm draws attention away from underlying structural causes that give rise to coercion and exploitation of migrant workers. Rather than focusing on prostitution and trafficking, she argues we must create new frameworks that center on the rights of the transnational migrant subject and give more attention to structural factors leading to forced labor generally. Kempadoo criticizes the anti-trafficking movement's global government approach that prioritizes crime, punishment, and immigration control, a framework that supports the neoliberal economic interests of corporations rather than the interests of the poor (Kempadoo, 2005). Similarly, Nandita Sharma (University of Hawaii) argues that the moral panic about sex 
trafficking serves to legitimate increasingly repressive state practices of immigration control while obscuring that migrants have been "displaced by practices that have resulted in the loss of their land and/or livelihoods through international trade liberalization policies, megadevelopment projects, the loss of employment in capitalist labor markets, or war" (Sharma 2005, 89). Similar to Kempadoo, Sharma argues that we must focus on safe migration rather than restricting migration. Emi koyama (2011a, 32) critiques criminal justice approaches to trafficking, urging "attention to the impact of poverty, racism, sexism, neoliberalistic global capitalism and its assault on the public safety net, homophobia and transphobia, and unjust immigration laws.” In the anti-trafficking movement, contends Elizabeth Bernstein $(2007,144)$, "masculinist institutions of big business, the state, and the police are reconfigured as allies and saviors, rather than oppressors, of unskilled migrant workers, and the responsibility for slavery is shifted from structural factors and dominant institutions onto individual, deviant men: foreign brown men...or even more remarkably, African American men living in the inner city." Abolitionist feminists and their critics both focus on the role of structural factors in the trafficking of women and girls, but they understand these factors in very different ways, which fuels their support of very different solutions to trafficking.

Some feminist scholars directly attack other feminists for being orientalist and imperialistic, particularly in the way that women of the global South are portrayed in antitrafficking discourses. Feminist abolitionists focus on the victimization of women in trafficking and the sex trade (Farley 2006; Jeffries 2009), whereas critics of these portrayals argue that the rhetoric of the anti-trafficking movement denies women and girls any sort of agency and reproduces traditional gender ideologies that disempower women and oppressed peoples globally (Bernstein 2007; Doezema 2001). Jo Doezema argues that western feminists position third world 
prostitutes as backward and helpless victims in need of rescue so that they then position themselves as rescuers. She argues, "through the injured third world woman's body, the saving western body is marked and maintained" (Doezema, 2001, 31). She argues that they advocate for protectionist laws that discipline third world women by restricting the mobility. Similarly, Kempadoo (2006) criticizes feminists who, she argues, "have formed alliances with neoconservative governments and Christian fundamentalists to demand an end to women's rights to sexual self-determination and autonomy" (xii). She critiques this coalition for constructing women only as victims with no agency thereby reproducing a very traditional and paternalistic gender ideology in which women are seen as "helpless and pitiful, passive and child-like, requiring rescue or saving, by others who know best" (xxiv). Kempadoo calls for an open, interactive, participatory process to "develop policies that empower and liberate poor communities in the global South from the devastations of twenty-first century globalization" (xxviii). Critical of scholars who "intervene in debates [about trafficking] from their ivory towers" (ix), Kempadoo claims to be working on the problem from the ground up.

Some scholars and activists try to walk a line between these two poles, like Rhacel Salazar Parreñas (2006). Parreñas, who is a professor of anthropology at University of Southern California, conducted in-depth research into the impact of anti-trafficking legislation on the lives of Filipino women working in Tokyo's nightlife industry. Under pressure from the United States, the Philippines imposed stronger restrictions on migrating hostess workers, whom policymakers considered to be highly vulnerable to trafficking. Through participant oberservation, Parreñas reveals the negative impact of United States anti-trafficking policy on Filipino hostess workers, which rather than protecting the women made migration more expensive and dangerous. While critical of the trafficking framework, Parreñas does not reject it, but focuses on coercive structural conditions, like restrictions on migration, as the primary contributing factor to 
women's vulnerability to trafficking rather than individual offenders or criminal networks. Another feminist who resists categorization is emi koyama. In addition to her longstanding criticisms of abolitionists, koyama has recently become critical of the "mainstream sex workers rights movement" and some who benefit from the sex industry, like Village Voice Media, for using her research to argue that sex trafficking is not a problem and that there are very few minors in the sex trade $(2011 \mathrm{~b}, 1)$. She is critical of those who profit from the sex trade but ignore exploitation of marginal populations within the sex trade.

Whereas some feminist scholars invoke race, class and nation to support United States policies of intervention and criminal justice solutions to trafficking, other feminists critique mainstream anti-trafficking rhetoric and activism (including that of feminist abolitionists) for relying on simplistic and universalizing narratives of gender and sexuality that undermine female agency, reinforce stereotypes of female victimization and sexual naivité, particularly of women in developing countries, and lead to laws that are oppressive to women, sexual minorities, and people of color.

\section{Conclusion}

The uniform condemnation of human trafficking does not mean there is a consensus about what human trafficking is or how to address it. In fact, the issue is very divisive, generating intense debates about definitions of human trafficking, the scope of the problem, causes of and solutions to human trafficking, the effectiveness and impact of anti-trafficking laws, and anti-trafficking discourses. Understanding these debates, particularly among feminists, is helpful to understanding and evaluating research and public policy on human trafficking. Current feminist debates on trafficking echo the 1980s feminist debates on prostitution and pornography. On the heels of the sexual revolution of the 1960s and 1970s, the 1980s feminist 
sex wars grew out of anxieties about changing norms around gender and sexuality (Bronstein, 2011). Similarly, the post-9/11 anti-trafficking movement has also grown out of anxieties about gender and sexuality, but in a distinctly globalized context, including the mass migration of women as well as exploitative global economic systems built on female labor (Barker \& Feiner, 2004; Enloe, 2007). Current feminist debates about consent and coercion related to commercialized sex reach a much wider range of issues in this globalized context, including women's right to migrate, female sexual autonomy, and relationships of women in the Global North to women in the Global South. These feminist debates are important to understanding human trafficking because they help to clarify the impact of anti-trafficking policies and practices on women around the world, and they provide guidance on how activists might function effectively across national and cultural divides.

What these debates clearly reveal is a need for high quality research into the prevalence and patterns of human trafficking on which to base laws and public policies that will effectively address the problem. Some of the basic principles that feminists have agreed upon, despite their differences, should guide future research and policy. First, sex trafficking must be analyzed with an intersectional perspective, with attention to how intersections of gender, race, class, and nationality contribute to making some people vulnerable to trafficking. Second, a feminist perspective offers a structural analysis, focusing on the social, economic and political systems in society contribute to trafficking. Globally, these include economic institutions like the World Trade Organization, which has promulgated unfair trade relations, or the International Monetary Fund, which has imposed structural adjustment, privatization of public resources, and export production on poor countries. Within the United States, structural conditions that support sex trafficking are the lack of government services to the poor and homeless youth, or the failure to 
address homophobia in society. Third, feminists focus on women's empowerment, asking whether anti-trafficking policies or programs empower women or merely rescue them, and whether they change the conditions of women's lives. Fourth, a feminist perspective encourages an awareness of positionalities: for example, how race, nationality, economics, or survivor status might impact the relationships between activists and victims. Awareness of positionalities might also ask whether anti-trafficking activities are reproducing the Western gaze- - the tendency to depict people, particularly in Southeast Asia, through the eyes of Westerners, which results in perpetuation of the Eurocentric gaze and in the representation of people as "other," strange and foreign. Also, an awareness of positionalities would pay attention to the historical moment by considering how anti-trafficking policies play into the post $9 / 11$ security state, leading to sealing up borders and ejecting immigrants; how anxieties about non-normative sexualities might factor in; and how anti-trafficking discourses might reproduce neo-colonial narratives, like white westerners saving brown women from brown men or civilizing "backward" cultures. Finally, a feminist approach to trafficking would try to make local/global connections, considering how United States policies on issues like war, trade, drugs and even forestry and conservation might exacerbate sex trafficking. These basic principles should inform future research and public policy—an analysis that focuses on intersectionality, structural conditions, women's empowerment, an awareness of positionalities and the historical moment, and making connections to women globally—principles upon which all feminists can agree. 
HUMAN TRAFFICKING DEBATES

\section{Reference List}

Agustin, L. (2007). Sex at the margins: Migration, labour markets and the rescue industry. London: Zed Books.

An act relative to the commercial exploitation of people. (2011). Mass. Gen. Laws ch. 265, §49, November 21, 2011.

Baker, C. (2013a). An intersectional analysis of sex trafficking films," Merdians: feminism, race, transnationalism 12, no. 1 (Spring 2014): 208-226.

Baker, C. (2013b). Moving beyond 'slavers, sinners, and saviors': An intersectional feminist analysis of U.S. sex trafficking discourses, law and policy. Journal of Feminist Scholarship 4 (Spring). Retrieved from http://www.jfsonline.org/issue4/pdfs/baker.pdf

Baker, Carrie N. (2012). The influence of international human trafficking on United States prostitution laws: The case of expungement laws." Syracuse Law Review 62 (2012): 17182.

Barker, D. \& Feiner, S. (2004). Liberating economics: Feminist perspectives on families, work and globalization. Ann Arbor, MI: University of Michigan Press.

Bernstein, E. (2010). Militarized humanitarianism meets carceral feminism: The politics of sex, rights, and freedom in contemporary antitrafficking campaigns. Signs: Journal of Women in Culture and Society, 36(1), 45-71.

Bernstein, E. (2007). The sexual politics of the "new abolitionism." differences: A Journal of Feminist Cultural Studies, 18(3), 129-151.

Bindman, J. (1997). Redefining prostitution as sex work on the international agenda. Network of Sex Work Projects.

Bronstein, C. (2011). Battling pornography: The American feminist anti-pornography movement, 1976-1986. New York, NY: Cambridge University Press. 
HUMAN TRAFFICKING DEBATES

Bumiller, K. (2008). In an abusive state: How neoliberalism appropriated the feminist movement against sexual violence. Durham, NC: Duke University Press.

Bush, G. W. (2002). National security Presidential directive/NSPD-22. Combatting trafficking in persons (December 16). http://www.combattrafficking.army.mil/documents/policy/NSPD-22.pdf

Center for Health and Gender Equity. (2008). Implications of U.S. policy restrictions for programs aimed at commercial sex workers. Takoma Park MD: Center for Health and Gender Equity.

Chapkis, W. (2003). Trafficking, migration and the law: Protecting innocents, punishing immigrants. Gender and Society, 17(6), 923-937.

Cizmar, M., Conklin, E. and Hinman, K. (2011, June 29). Real men get their facts straight: Ashton and Demi and sex trafficking. Village Voice.

Curtis, R., Terry, K., Dank, M., Dombrowski, K. \& Khan, B. (2008, September). The commercial sexual exploitation of children in New York City. New York, NY: Center for Court Innovation and John Jay College.

Davidson, J.O. (2010). New slavery, old binaries: Human trafficking and the borders of 'freedom.' Global Networks, 10(2), 244-261.

Davidson, J.O. (2005). Children in the global sex trade. Cambridge, England: Polity.

Ditmore, M. \& Thukral, J. (2012, June). Accountability and the use of raids to fight trafficking. Anti-Trafficking Review, 1, 134-148.

Doezema, J. (2001). Ouch!: Western feminists' 'wounded attachment' to the 'third world prostitute.' Feminist Review, 67, 16-38.

Doezema, J. (2000). Loose women or lost women?: The re-emergence of the myth of 'white slavery' in contemporary discourses of 'trafficking in women.' Gender Issues, 18(1), 23-50. 
HUMAN TRAFFICKING DEBATES

Duggan, L. \& Hunter, N.D. (2005). Sex wars: sexual dissent and political culture. New York: Routledge.

Enloe, C. (2007). Globalization and militarization: Feminists make the link. Lanham, MD: Rowman \& Littlefield Publishers.

Farley, M. (2006). Prostitution, trafficking and cultural amnesia: What we must not know in order to keep the business of sexual exploitation running smoothly. Yale Journal of Law and Feminism, 18(1), 109-144.

FUSE. (2011). "No simple solutions: State violence and the sex trade.” Incite! Blog, April 22. doi: http://inciteblog.wordpress.com/2011/04/22/no-simple-solutions-state-violence-and$\underline{\text { the-sex-trades/ }}$

Global Alliance Against Trafficking in Women. (2007). Collateral damage: The impact of antitrafficking measures on human rights around the world. Bangkok: Global Alliance Against Trafficking in Women.

Hua, J. (2011). Trafficking women's human rights. Minneapolis, MN: University of Minnesota Press.

Hua, J. \& Ray, K. (2010). The "practice of humanity": Neoliberal constructions of domestic workers and "sex slaves." Feminist Media Studies, 10(3), 253-267.

In our own backyard: Child prostitution and sex trafficking in the United States, A hearing before the United States senate judiciary subcommittee on human rights and law. $111^{\text {th }}$ Cong. 14 (2010, February 24) (testimony of Rachel Lloyd). doi: http://www.gpo.gov/fdsys/pkg/CHRG-111shrg58003/pdf/CHRG-111shrg58003.pdf International Labour Organization (2012). ILO 2012 global estimate of forced labor. Geneva, Switzerland: International Labour Organization. 
HUMAN TRAFFICKING DEBATES

Jeffries, S. (2009). The industrial vagina: The political economy of the global sex trade. New York, NY: Routledge.

Jordan, A. (2012). The Swedish law to criminalize clients: A failed experiment in social engineering. Issue Paper 4 (April). Program on Human Trafficking and Forced Labor, Center for Human Rights and Humanitarian Law, American University Washington College of Law. doi: http://rightswork.org/wp-content/uploads/2012/04/Issue-Paper-4.pdf

Kempadoo, K. (2005). Introduction, From moral panic to global justice: Changing perspectives on trafficking. In Kempadoo, K., Sanghera, J. \& Pattanaik, B. (Eds.), Trafficking and prostitution reconsidered: New perspectives on migration, sex work, and human rights. (pp. vii-Xxxiv.). Boulder, CO: Paradigm.

koyama, e. (2011a). War on terror \& war on trafficking: A sex worker activist confronts the antitrafficking movement. Portland, OR: Confluere Publications.

koyama, e. (2011b). Understanding the complexity of sex work/trade and trafficking. Portland, OR: Confluere Publications.

Landesman, P. (2004, January 25). The girls next door. New York Times Magazine, p. 30.

Lloyd, R. (2011). Girls like us: Fighting for a world where girls are not for sale, An activist finds her calling and heals herself. New York NY: Harper.

Lopez, K.J. (2006, January 26). The new abolitionist movement: Donna Hughes on progress fighting sex trafficking. National Review Online.

Lovell, R. \& Jordan, A. (2012). Do john's schools really reduce recidivism?, Washington D.C. and Chicago, IL: Program on Human Trafficking and Forced Labor, Center for Human Rights and Humanitarian Law, American University Washington College of Law and the Social Science Research Center, DePaul University. 
Miriam, K. (2005). Stopping the traffic in women: Power, agency, and abolition in feminist debates over sex-trafficking. Journal of Social Philosophy, 36(1), 1-17.

Mohanty, C. T. (2006). US Empire and the project of women's studies: Stories of citizenship, complicity and dissent. Gender, Place and Culture, 13(1), 7-20.

Office to Monitor and Combat Trafficking in Persons. (2012, July 12). The benefits of smart raids vs. blind sweeps. Washington D.C.: United States Department of State. doi: http://www.state.gov/j/tip/rls/fs/2012/194723.htm

Parreñas, R.S. (2006). Trafficked? Filipino hostesses in Tokyo's nightlife industry. Yale Journal of Law and Feminism, 18(1), 145-180.

Pierce, A. (2009). Shattered hearts: The commercial sexual exploitation of American Indian women and girls in Minnesota. Minneapolis, MN: Minnesota Indian Women's Resource Center.

Polaris Project. (2012). State ratings map. doi: http://www.polarisproject.org/what-we-do/policyadvocacy/current-laws\#state_reports

Protocol to prevent, suppress and punish trafficking in persons, especially women and children, supplementing the United Nations convention against transnational organized crime, November 15, 2000, 2237 U.N.T.S. 343.

Sharma, N. (2005). Anti-trafficking rhetoric and the making of a global apartheid. NWSA Journal, 17(3), 88-111.

Soderlund, G. (2005). Running from the rescuers: New U.S. crusades against sex trafficking and the rhetoric of abolition. NWSA Journal, 17(3), 64-87.

Spivak, G. C. (1988). Can the subaltern speak? In C. Nelson and L. Grossberg (Eds.), Marxism and the interpretation of culture. (pp. 271-313). Basingstoke, UK: Macmillan Education. 
HUMAN TRAFFICKING DEBATES

Stransky, M. \& Finkelhor, D. (2008). How many juveniles are involved in prostitution in the U.S.? Durham, NH: Crimes Against Children Research Center.

Temin, M., Montgomery, M., Engebretsen, S., \& Barker, K. (2013). Girls on the move: Adolescent girls \& migration in the developing world. New York, NY: Population Council.

Trafficking Victims Protection Act of 2000, Pub. L. No. 106-386, § 101, 22 U.S.C. $§ 7102$ et seq.

United States Agency for International Development v. Alliance for Open Society International, Inc., 570 U.S. _ (2013).

United States Government Accountability Office (US GAO). (2006, July). Human trafficking: Better data, strategy, and reported needed to enhance U.S. anti-trafficking efforts abroad (A report to the Chairman, Committee on the Judiciary and the Chairman, Committee on International Relations, House of Representatives) (GAO-06-825). Washington D.C.: US GAO.

Weitzer, R. (2011). Pornography's effects: The need for solid evidence. Violence Against Women, 17 (5), 666-675.

Weitzer, R. (2007). The social construction of sex trafficking: Ideology and institutionalization of a moral crusade. Politics \& Society, 35(3), pp. 447-475.

Wyler, L.S. \& Siskin, A. (2010, February 18). Trafficking in persons: U.S. policy and issues for Congress. Washington D.C.: Congressional Research Service.

Iman, J., Fullwood, C., Paz, N., W., D. \& Hassan S. (2009). Girls do what they have to do to survive: Illuminating methods used by girls in the sex trade and street economy to fight back and heal. Chicago, IL: Young Women's Empowerment Project. 